\title{
Diffusion bonding and brazing of high purity copper for linear collider accelerator structures
}

\author{
J. W. Elmer, J. Klingmann, and K. Van Bibber \\ Lawrence Livermore National Laboratory, Livermore, California 94551 \\ (Received 24 February 2000; published 23 May 2001)
}

\begin{abstract}
Diffusion bonding and brazing of high purity copper were investigated to develop procedures for joining precision machined copper components for the Next Linear Collider (NLC). Diffusion bonds were made over a range of temperatures from $400{ }^{\circ} \mathrm{C}$ to $1000{ }^{\circ} \mathrm{C}$, under two different loading conditions [3.45 $\mathrm{kPa}(0.5 \mathrm{psi})$ and $3.45 \mathrm{MPa}(500 \mathrm{psi})$ ], and on two different diamond machined surface finishes. Brazes were made using pure silver, pure gold, and gold-nickel alloys, and different heating rates produced by both radiation and induction heating. Braze materials were applied by both physical vapor deposition (PVD) and conventional braze alloy shims. Results of the diffusion bonding experiments showed that bond strengths very near that of the copper base metal could be made at bonding temperatures of $700{ }^{\circ} \mathrm{C}$ or higher at $3.45 \mathrm{MPa}$ bonding pressure. At lower temperatures, only partial strength diffusion bonds could be made. At low bonding pressures $(3.45 \mathrm{kPa})$, full strength bonds were made at temperatures of $800{ }^{\circ} \mathrm{C}$ and higher, while no bonding (zero strength) was observed at temperatures of $700{ }^{\circ} \mathrm{C}$ and lower. Observations of the fracture surfaces of the diffusion bonded samples showed the effects of surface finish on the bonding mechanism. These observations clearly indicate that bonding began by point asperity contact, and flatter surfaces resulted in a higher percentage of bonded area under similar bonding conditions. Results of the brazing experiments indicated that pure silver worked very well for brazing under both conventional and high heating rate scenarios. Similarly, pure silver brazed well for both the PVD layers and the braze alloy shims. The gold and gold-containing brazes had problems, mainly due to the high diffusivity of gold in copper. These problems led to the necessity of overdriving the temperature to ensure melting, the presence of porosity in the joint, and very wide braze joints. Based on the overall findings of this study, a two-step joining method is proposed for fabricating the NLC structures. The structure would be assembled with pure silver braze inserts using a self-aligning step joint design, then the assembly would be vacuum diffusion bonded at $700{ }^{\circ} \mathrm{C}$ and $3.45 \mathrm{MPa}$ pressure to seal the critical inner portion of the assembly. Finally, during the same furnace cycle, the temperature would be increased to $800{ }^{\circ} \mathrm{C}$ in order to react the silver with the copper to form a liquid braze alloy that would join and seal the outer portion of the cells together.
\end{abstract}

DOI: $10.1103 /$ PhysRevSTAB.4.053502

PACS numbers: 29.17.+w

\section{INTRODUCTION}

The Next Linear Collider (NLC) is a proposed $30 \mathrm{~km}$ long $\mathrm{TeV}$-class electron-positron collider designed with the new high-gradient $X$-band technology [1]. At the heart of the NLC are two opposing linacs operating at accelerating gradients upwards of $75 \mathrm{MeV} / \mathrm{m}$. Each linac is $10 \mathrm{~km}$ long and is designed with a highly repetitive architecture whereby three $1.8 \mathrm{~m}$ long structures are mounted into one superstructure. Each of these structures contains 206 cells, which are diffusion bonded together, onto which couplers and water cooling is then brazed. The entire linac is thus made up of tens of thousands of these cells which, when finally assembled, must maintain exceptional alignment tolerances, must have exceptional electrical properties, and must be vacuum tight.

A critical design feature of the NLC is the dampeddetuned structure (DDS) shown in Fig. 1 [2]. In this design, unwanted beam-deflection modes (TM) within each structure are spread out in frequency, in an approximately Gaussian distribution. This "detuning" is done in order to cancel the wakefields excited by off-axis beam bunches, which would disrupt bunches following in train. The energy associated with the deflecting modes is then coupled out to manifolds within the structure itself, propagating to lossy loads at each end - referred to as "damping." The cost of the detuning and damping features of the structure is increased complexity. No two cells in the structure are identical, rotational symmetry is broken, and the cells require a through-milling step to establish the damping

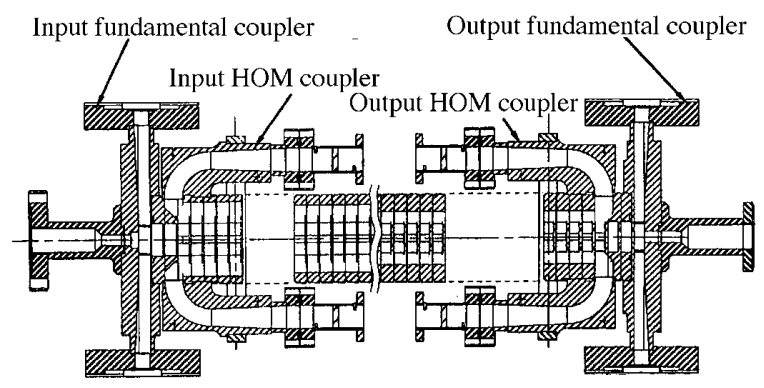

FIG. 1. Cross section of the DDS-3 structure. 
manifold, as seen in Fig. 2 [2]. Refinements of the electromagnetic design are periodically implemented in the DDS $n$ series of structures, but do not significantly affect the basic mechanical design. Thus, this work will be relevant to the final detailed cell shape. We believe our experi-
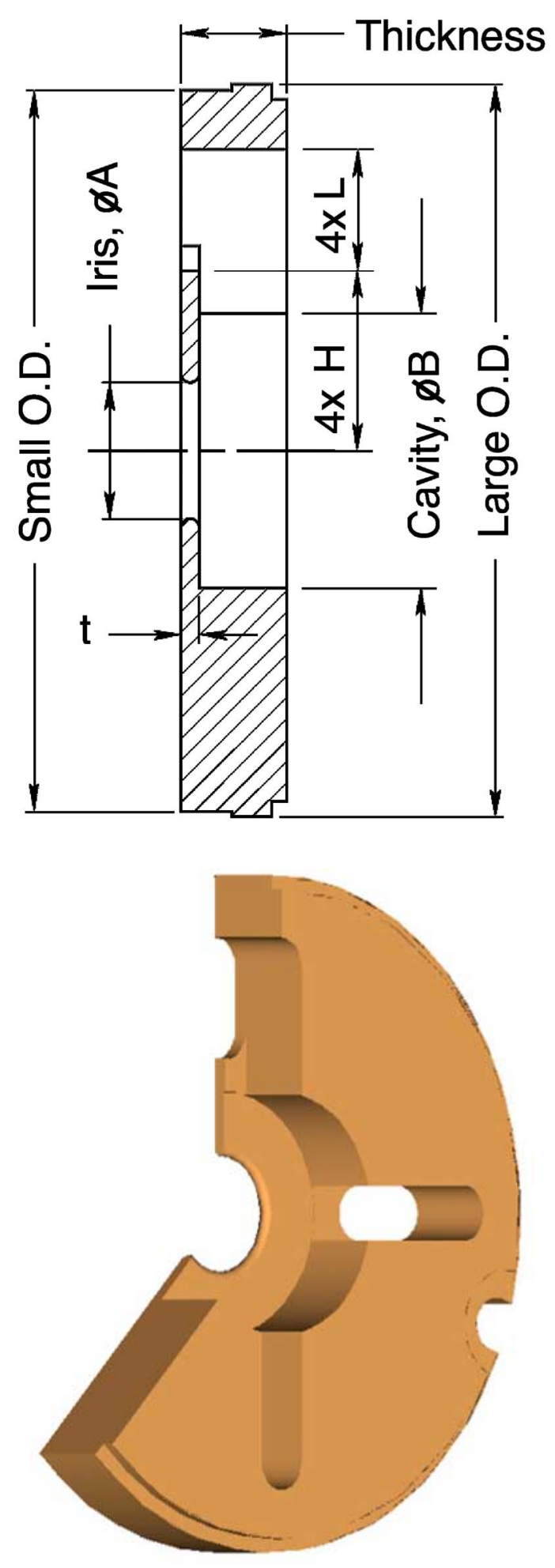

FIG. 2. (Color) Cross section and rendering of the DDS-3 cell. ence may also prove useful to other future linear collider designs.

To succeed, the NLC program will need to resolve several key advanced fabrication challenges. Precision machining of the individual cells will be accomplished by diamond machining [3]. Although this technology is not new, the fabrication of 2000 cells per day required for a 3-yr build presents engineering challenges. The problem is further complicated in that none of the cells in each $1.8 \mathrm{~m}$ long structure are identical. Once the cells are machined, they must be bonded together into structures while maintaining micrometer-per-meter tolerances on the finished part. Current technology for fabricating these structures consists of diffusion bonding the copper faces of each cell together in a hydrogen atmosphere [4] or in vacuum [5]. This diffusion bonding process is more accurate in its effect on axial dimensions than brazing processes, which have been investigated. However, in high volume production of structures, it will be necessary to reduce the bonding joint requirement to one of repeatability where, depending on the cell location in the stack, the bond joint thickness is repeatable to the submicrometer level. This approach will require the calibration of the bonding or brazing process, and the cell dimensions account for this calibration, including the inherent weight of the structure which increases from the top to the bottom of the stack. This means that thin braze joints should be acceptable for the production structure problem.

This paper reports our experience with brazing and diffusion bonding, which is the basis for all schemes for copper structure fabrication presently under consideration. We consider a hybrid process for fabricating the structures that involves both vacuum brazing and diffusion bonding, which was considered in the past [6]. In this process, the critical dimensional tolerances of the important inner portion of the assembly are maintained by a diffusion bond, while the strength and hermiticity of the structure is maintained by a vacuum braze. In addition we propose a step-joint cell design that is self-aligning to facilitate assembly.

\section{EXPERIMENTAL PROCEDURES}

\section{A. Materials}

Small test coupons were used for the brazing and bonding studies. Figure 3(a) shows the sample geometry that consists of a right circular cylinder with a reduced section having a diameter of $12 \mathrm{~mm}$ and a small hole drilled through the center. The small hole in the center of the coupon reduced the cost of manufacturing by eliminating the likelihood of an on-center imperfection of the flat bonding surface. Such an imperfection would cause a gap between the two coupons during bonding or brazing, leading to erroneous data. Brazing and bonding studies were performed by joining two identical samples together to create a bonded part that is joined at its midpoint, as shown 

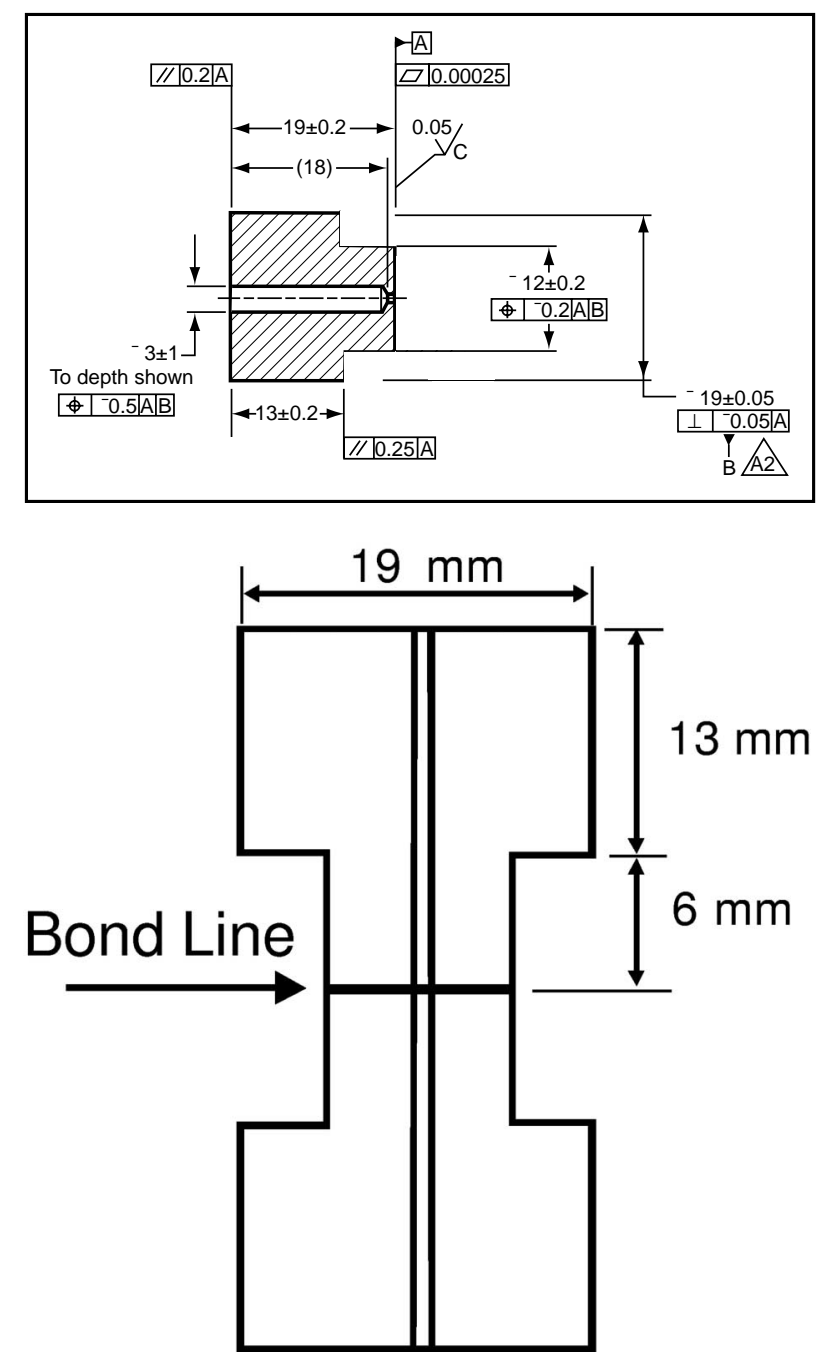

FIG. 3. (Top) Schematic of the reduced section sample before bonding. (Bottom) Reduced section sample after bonding.

in Fig. 3(b). Some test samples were designed without a reduced section and without a hole drilled in the center. All samples were made from oxygen-free electronic grade copper, UNS C10100, which was purchased in $20 \mathrm{~mm}$ diameter bar stock in the full hard condition and contained a minimum of $99.99 \% \mathrm{Cu}$.

The critical dimensional tolerances of the accelerator cells require precision machining methods for cell fabrication. Diamond turning and/or fly cutting was chosen to produce these parts because it generates accurate surfaces with extremely low levels of contamination, compared with abrasive processes, and very low residual stress, creating ideal conditions for diffusion bonding. Alternatively, cells can be lapped to generate the desired surface finish and necessary flatness for bonding. Although lapping can generate a better surface finish than diamond turning, i.e., errors with wavelength scale less than $0.8 \mathrm{~mm}$ per ANSI/ASME B46.1-1985, it can introduce problems as well. The cells must be exceptionally clean for the in- tended high-gradient applications in order to sustain very high field gradients at the rf surfaces without breakdown, and it is essentially impossible to lap only the bonding surface without collateral contamination of the cell region. This contamination cannot be reliably removed by subsequent chemical cleaning, and lapping also produces surfaces with "roll off" or taper near the edges.

The diamond-turned test samples were annealed in vacuum at $1 \times 10^{-6}$ torr after rough machining and just prior to diamond machining, in order to remove any nonuniform residual stresses that may have been induced in the parts. This annealing cycle helped to mechanically stabilize the surfaces to be bonded and also helped to soften the copper prior to diffusion bonding. The annealing cycle consisted of heating the samples at a controlled rate of $200{ }^{\circ} \mathrm{C} / \mathrm{h}$ to the annealing temperature of $500{ }^{\circ} \mathrm{C}$, holding the parts at this temperature for $1 \mathrm{~h}$, and furnace cooling to ambient in vacuum. During annealing at $500{ }^{\circ} \mathrm{C}$, the copper recrystallized and dropped in hardness from diamond pyramid hardness (DPH) 91 to DPH 49 as measured with a $1.0 \mathrm{~N}$ load.

After diamond machining, the parts were cleaned to remove the mineral oil that was used as a cutting lubricant. Initially, an acetone rinse was used in an attempt to remove the oil, but this method proved to be ineffective and other methods were investigated. The cleaning process found to be successful consisted of (i) a pressure-free swipe with a lint-free cotton cloth to remove the bulk of the mineral oil,

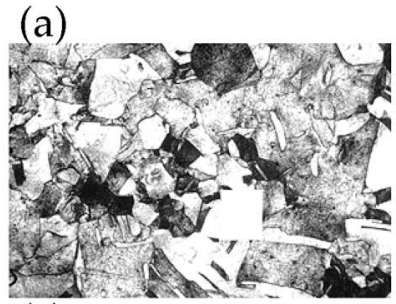

(c)

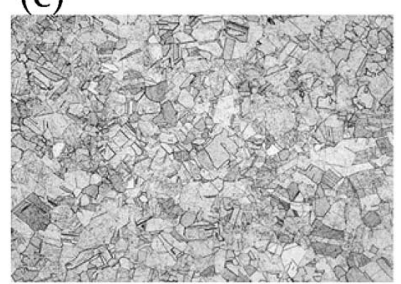

(e)

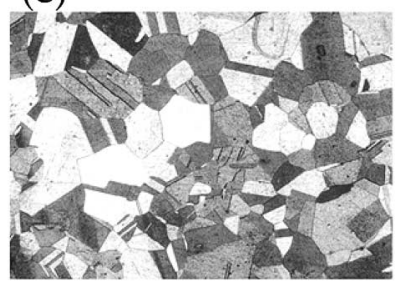

(b)

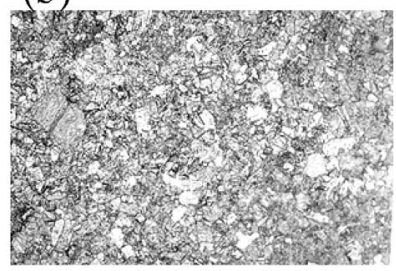

(d)

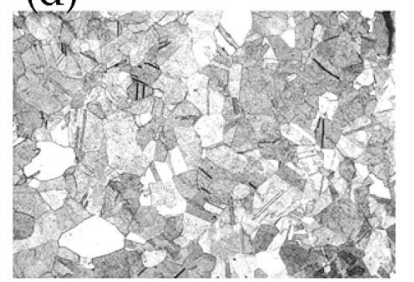

(f)

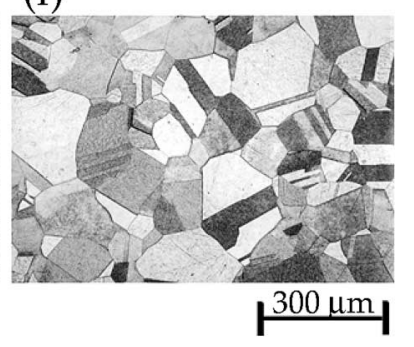

FIG. 4. Microstructures of high purity copper after annealing in vacuum for $30 \mathrm{~min}$ at (a) room temperature as received, (b) $600{ }^{\circ} \mathrm{C}$, (c) $700{ }^{\circ} \mathrm{C}$, (d) $800{ }^{\circ} \mathrm{C}$, (e) $900{ }^{\circ} \mathrm{C}$, and (f) $1000{ }^{\circ} \mathrm{C}$. 
TABLE I. ASTM grain size number of samples bonded at different temperatures.

\begin{tabular}{lcccccc}
\hline \hline Bonding temperature & As received & $600{ }^{\circ} \mathrm{C}$ & $700{ }^{\circ} \mathrm{C}$ & $800{ }^{\circ} \mathrm{C}$ & $900{ }^{\circ} \mathrm{C}$ & $1000^{\circ} \mathrm{C}$ \\
ASTM grain size & 2.5 & 6 & 5 & 4 & 2.5 & 1 \\
\hline \hline
\end{tabular}

(ii) ultrasonic cleaning in trichloroethylene, (iii) ultrasonic cleaning in reagent grade ethanol, and (iv) blow-drying with nitrogen gas.

The elevated temperature conditions that are used during brazing and bonding resulted in recrystallization and grain growth of the copper. These changes were investigated by inspecting the microstructure of samples that had been annealed for $30 \mathrm{~min}$ at temperatures as high as $1000{ }^{\circ} \mathrm{C}$. Figure 4 shows micrographs of these samples after annealing, and Table I summarizes the results of grain size measurements. The grain size of the parts decreases from American Society for Testing Materials (ASTM) 2.5 in the as-received condition to ASTM 6 at the $600{ }^{\circ} \mathrm{C}$ anneal. This decrease in grain size is due to recrystallization of the copper. At higher bonding temperatures, the grain size of the copper increases so that after $900{ }^{\circ} \mathrm{C}$ it has returned to ASTM 2.5. Grains continue to grow at higher temperatures, reaching ASTM 1 after the $1000{ }^{\circ} \mathrm{C}$ heat treatment.

\section{B. Precision machining}

The coupons were rough and finish (diamond) machined at a commercial vendor. The heat treat condition of the material was as received, typically half-to-full hard. The drawing specification was for a critical (bonding) surface flatness of $0.25 \mathrm{~mm}$ and a surface finish of $500 \AA \mathrm{Ra}$. An important point to note is that the rough parts were not annealed as was the usual procedure for NLC accelerator cells $\left(500{ }^{\circ} \mathrm{C}\right.$ for $1 \mathrm{~h}$ in vacuum). The vendor used a diamond fly-cutting operation to finish the bonding surfaces of the coupons. Two problems became apparent when the (a)

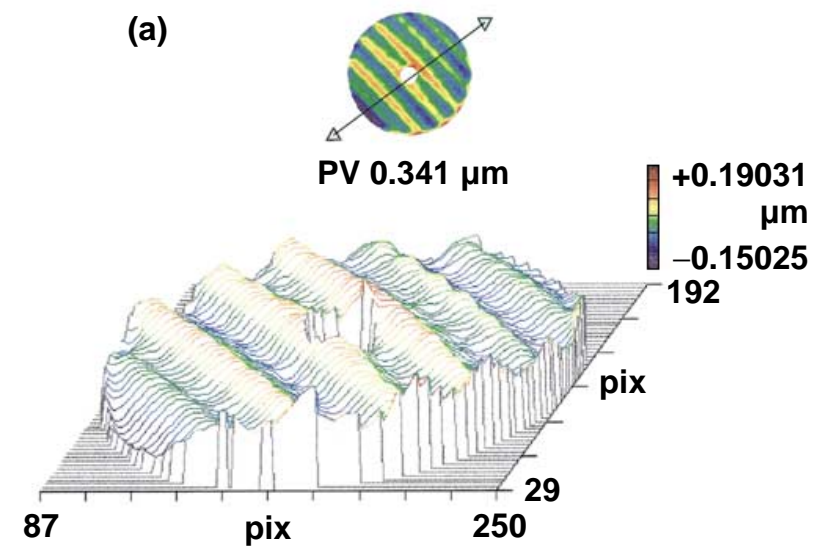

(b)

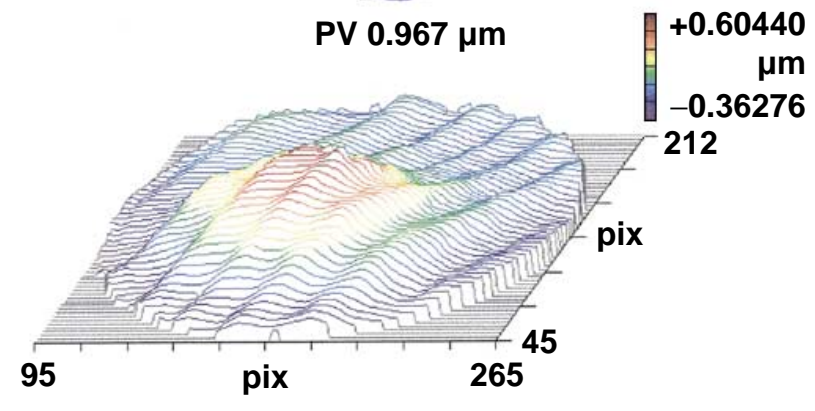

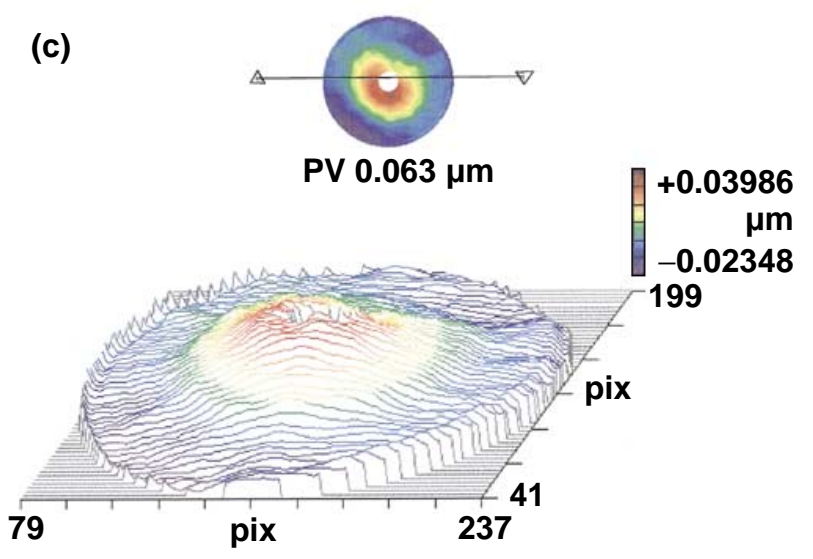

FIG. 5. (Color) Inspection records of the two diamond-machined surfaces. (a) Surface produced by diamond fly cutting of an unannealed part. Note the waviness of the surface. (b) Surface produced by postannealing a diamond fly-cut part. Note the deformation due to stress relief around the center hole. (c) Surface produced by diamond turning of an annealed surface. The flatness is less than $100 \mathrm{~nm}$. 
parts were received at LLNL. First, without regard to surface error spatial wavelength, the flatness of the flycut parts was acceptable; however, there was approximately $2 \mathrm{~mm}$ wavelength waviness on the finished surface, probably due to an error motion in the $X$ machine slide. Figure 5(a) shows an interferogram of this effect. As discussed in Sec. IIE, this effect caused a regular gridlike, multipoint bonding pattern where the local high points contacted. The second problem was due to omitting the annealing step on these parts prior to diamond fly cutting. The result was that, as the parts were warmed during a bonding test, the surfaces annealed and deformed, mostly locally around the center hole probably due to high stresses incurred during the hole drilling operation. Figure 5(b) shows an interferogram of this effect. This second problem resulted in poor simulation of the actual NLC bonding conditions and, therefore, the parts had to be annealed and recut (turned) with diamond tools. This operation, performed at LLNL, resulted in parts with surface figure typically below $100 \mathrm{~nm}$ and finishes within the $500 \AA$ specification. Figure 5(c) shows an interferogram of a typical surface. For verification, a second anneal was performed, which did not degrade the surface figure of these parts.

\section{Deburring}

Small burrs were present on the edges of the parts after rough machining. These burrs were unacceptable in that they may interfere with the bonding operation and may not be removed completely by diamond machining. The present method of deburring the rough machined parts is to hand work them with small tools to remove any of the excess material; however, this method is very time consuming and can scratch the surfaces if not properly performed. An alternate method of deburring that involves a thermal process to flash burn off the burrs was pursued. This thermal deburring process consisted of placing the parts to be deburred into an autoclave and filling the autoclave with a combustible mixture of gases. When combusted, rapid thermal heating occurs and preferentially attacks the small burrs due to their small thermal mass, burning them off of the surface while nominally leaving the remainder of the part unaffected.

Several copper parts were treated using this thermal deburring process on a trial basis [7]. The deburring process worked well in removing the burrs, and the treated parts were then ready for diamond turning with no further deburring required. However, the thermally deburred parts caused rapid tool wear during diamond turning as compared with those deburred by hand. An investigation of this effect using x-ray photoelectron spectroscopy (XPS) [8] showed that the surface of the thermally deburred parts contained small amounts of chromium. It is known that chromium will react with the diamond tool during machining [9] and is suspected to be responsible for the reduced tool life. The source of the chromium is believed to be from the proprietary thermal deburring process whereby chromium was transferred from the autoclave walls to the surface of the copper parts.

Although we did not use thermal deburring for the test samples that were manufactured in this study at LLNL, the thermal deburring process has potential for reducing cost in the NLC production. However, additional studies need to be performed in order to understand the thermal deburring process so that it can be better controlled to eliminate the source of chromium or any other deleterious elements from contaminating the copper parts.

\section{Brazing}

A braze was designed which would join the cells and supplement the diffusion bond in order to add strength and provide the vacuum seal. Since brazing can be performed on rougher surfaces than diffusion bonding, brazing could also be used to reduce the amount of area that would have to be diamond machined prior to diffusion bonding. This reduction in the amount of area that needs to be diamond machined could be used to increase production speed and lower the overall cost of the NLC accelerator structures.

Vacuum brazing was performed on the test samples using braze materials based on silver and gold, and these alloys were applied by two different methods. The first method utilized thin ( 25 to $50 \mu \mathrm{m}$ thick) braze alloy shims to join the parts. The second method utilized the more precise method of braze alloy placement by physical vapor deposition (PVD) onto the surfaces to be joined. The second method allowed the braze alloy to be deposited in very thin layers ( $3 \mu \mathrm{m}$ for example), but is more costly to apply than the conventional shim method.

The PVD braze alloy coatings were applied to the diamond-turned surfaces in a vacuum chamber which was prepumped to $1 \times 10^{-8}$ torr prior to backfilling with 40 mtorr of Ar. The surfaces of the parts to be coated were first argon-ion sputter etched inside the chamber at $1000 \mathrm{~V} \mathrm{dc}$ with a $1 \mathrm{~mA}$ current for $30 \mathrm{~min}$, and then the coatings were applied by reversing the polarity and argon-ion sputtering high-purity targets. Coatings of pure silver, pure gold, and pure nickel were deposited with different thicknesses from 1 to $3 \mu \mathrm{m}$ per face. The sputter targets measured $63.5 \mathrm{~mm}$ diameter and were of $99.999 \%$ purity. The typical sputter coating operating conditions were $350 \mathrm{~V}$ and $0.4 \mathrm{~A}$, with a source to table distance of $105 \mathrm{~mm}$. These conditions yielded a deposition rate of $20 \AA / \mathrm{sec}$ as determined by profilometry across a deposition step on a silicon witness sample. After coating, the samples were placed in a desiccator until they were ready to be brazed.

After application of the braze alloy, the parts to be joined were placed in a vacuum brazing furnace at $1 \times 10^{-6}$ torr pressure, and were brazed using two different heating methods. The first method involved furnace brazing with 
radiation heating elements that heated the parts at rates on the order of $10{ }^{\circ} \mathrm{C} / \mathrm{min}$ to $100{ }^{\circ} \mathrm{C} / \mathrm{min}$. The second method involved furnace brazing with induction heating. This method allowed heating rates up to $250^{\circ} \mathrm{C} / \mathrm{min}$ to be used. In both cases, the joint was heated to a temperature slightly below the braze temperature where it was held for a few minutes for temperature equalization. The joint was then made by heating to the braze temperature, where the parts were held for approximately $1 \mathrm{~min}$. The brazed parts were then furnace cooled to $100{ }^{\circ} \mathrm{C}$ or less in vacuum prior to opening the chamber.

\section{E. Diffusion bonding}

The diamond-machined copper test samples were diffusion bonded by heating in vacuum using two different uniaxial loading conditions and two different surface finishes. The samples were heated at a rate of $15^{\circ} \mathrm{C} / \mathrm{min}$ to the bonding temperature, held at this temperature for $30 \mathrm{~min}$, and furnace cooled to ambient. Figure 3(b) showed the diffusion bonded sample geometry having a reduced cross section. After bonding, the diffusion bonded samples resembled small cylindrical tensile test bars, which enabled the samples to be pulled in tension to determine the strength of the bond. Since these samples were not originally designed for tensile testing, the proportions of the samples were not made to any standard configuration, and the small hole bored down the center of the part further altered the sample geometry. Nevertheless, this nonstandard test geometry was useful in providing a relative bond strength that could be used to compare the effectiveness of different bonding conditions.

Mechanical testing of the bonded samples was performed at room temperature using a screw-driven uniaxial testing machine. The tensile strain was applied at a rate of approximately $5 \times 10^{-3} / \mathrm{s}$, and the peak load for the joint was recorded. All samples fractured at the bond line, and the fracture surfaces were carefully stored for later inspection.

\section{RESULTS}

\section{A. Vacuum brazing-sputter deposited coatings}

\section{Silver coatings}

Silver and copper form a low melting point eutectic alloy, which melts at $780{ }^{\circ} \mathrm{C}$ and has a composition of 28 wt. $\% \mathrm{Cu}$ and 72 wt. \% Ag [10]. Thus, the sputter deposited thin layer of pure silver on the copper cell begins to react with the copper to form a liquid when the part has been heated to the eutectic temperature of $780^{\circ} \mathrm{C}$. The liquid layer that forms will increase in thickness as the silver layer reacts with the copper, and eventually all of the silver will be consumed by the liquid to form the braze. The thickness of the final braze is related to the original thickness of the silver layer, the brazing temperature, and the thermal cycling conditions. If held at elevated tempera- tures long enough, the liquid will isothermally solidify as silver diffuses out of the liquid and into the copper [11].

Silver coatings were applied directly by PVD to each of the copper surfaces to be joined. These $4 \mu \mathrm{m}$ thick coatings were kept in a desiccator prior to bonding. The brazing schedule consisted of heating the sample to $770{ }^{\circ} \mathrm{C}$ in $30 \mathrm{~min}$, holding at $770{ }^{\circ} \mathrm{C}$ for $5 \mathrm{~min}$, heating to $800^{\circ} \mathrm{C}$ in $5 \mathrm{~min}$, and holding at $800^{\circ} \mathrm{C}$ for $2 \mathrm{~min}$, followed by furnace cooling to ambient. Figure 6 shows the microstructure of the braze joint, indicating that a $16 \mu \mathrm{m}$ thick eutectic liquid layer had been created at the joint interface. Diffusion of the silver into the copper base metal also occurred at these temperatures to form a $4 \mu \mathrm{m}$ wide boundary outside the liquid zone. During brazing, porosity developed in the joint (not shown in Fig. 6), which increased the overall thickness to more than what would be expected for this joint. In addition, it is believed that the inherent pressure applied by the weight of the parts $(1.08 \mathrm{kPa})$ was not sufficient to keep the upper piece from "floating" during brazing. This also resulted in contributing to the width of the joint. Later tests done on the reduced section joints where the average interfacial pressure was higher $(3.45 \mathrm{kPa})$ produced thin joints and seemed to confirm this observation.

These pure silver braze results were very positive, showing that thin layers of PVD deposited silver can be used to produce braze joints under normal furnace brazing conditions. However, it was determined that the interfacial pressure of $1.08 \mathrm{kPa}$ was not sufficient to produce a tight silver joint, and additional tests are required to determine the minimum pressure to apply to this joint. It is believed that this joint could be produced to the necessary thickness repeatability for the production structure problem. Since different locations in the stack are subjected to different pressures due to gravity loading over the stack height, multiple bonding tests were made at various pressures to

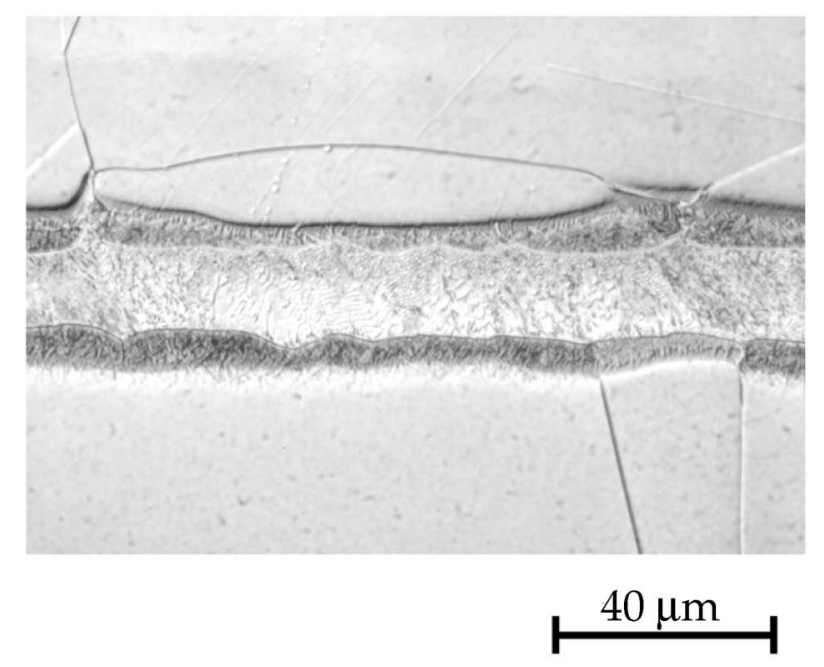

FIG. 6. Microstructure of a pure silver PVD vacuum furnace braze showing the eutectic liquid braze. 
simulate different stack locations would determine the repeatability of the brazing step.

\section{Gold coatings}

Gold-copper alloys have melting points that vary with the alloy composition such that there is a minimum melting point at $910{ }^{\circ} \mathrm{C}$ for a composition 20 wt. $\% \mathrm{Cu}$ and 80 wt. \% Au [10]. Therefore, a thin gold layer placed on a copper surface should begin to react to form liquid when the sample is heated to $910{ }^{\circ} \mathrm{C}$. However, $\mathrm{Cu}$ and $\mathrm{Au}$ are mutually soluble [10], and the diffusivity of gold in copper is very high. These factors can result in gold diffusing far enough away from the original joint interface during heating to the braze temperature to increase the melting point of the joint substantially. The distance that gold diffuses away from the interface depends on the heating rate of the braze and the braze temperature, and can be estimated from a simple diffusion calculation.

The diffusion of gold in copper has an activation energy of $Q=197.8 \mathrm{~kJ} / \mathrm{mole}$ and a preexponential coefficient of $A=0.243 \mathrm{~cm}^{2} / \mathrm{s}$ [12]. Therefore, one can estimate the average diffusion distance that occurs during the nonisothermal temperature spike by integrating the diffusion distance $X=2(D t)^{1 / 2}$ [13] with respect to time, from the start to the finish of the brazing cycle. In this expression, $D$ is the diffusion coefficient $D=$ $A \exp (-Q / R T), t$ is the brazing time, $X$ is the diffusion distance, $R$ is the gas constant $(8.314 \mathrm{~kJ} / \mathrm{mole})$, and $T$ is the absolute temperature. Heating rates on the order of $10{ }^{\circ} \mathrm{C} / \mathrm{min}$ are typical in conventional furnace brazing, and, under this condition, the diffusion distance of gold was estimated to be $34 \mu \mathrm{m}$ from the original joint interface. This estimate was made by integrating the diffusion distance $X$ with time, over the duration of the heating cycle to the braze temperature of $910{ }^{\circ} \mathrm{C}$. For $\mu \mathrm{m}$-thick gold layers, this diffusion of gold away from the interface dilutes the amount of gold at the interface considerably, thus raising the melting temperature of the joint to over $100{ }^{\circ} \mathrm{C}$ as indicated by the $\mathrm{Au}-\mathrm{Cu}$ phase diagram [10].

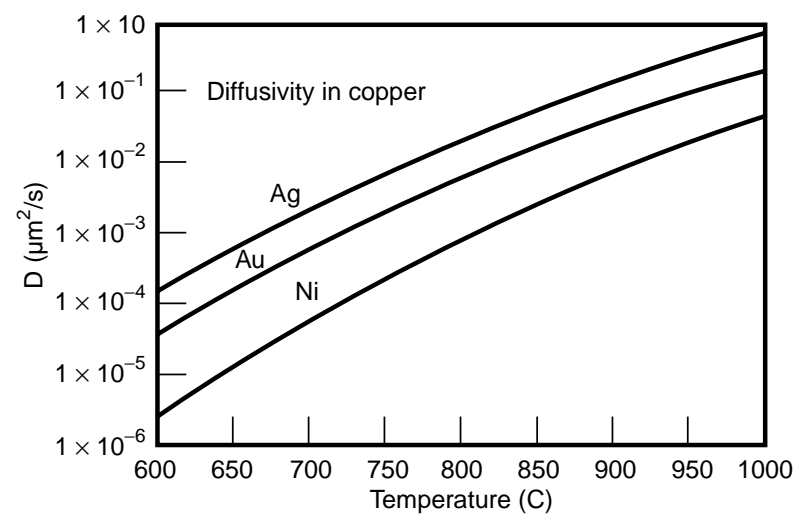

FIG. 7. Comparison of the diffusivity of $\mathrm{Ag}, \mathrm{Au}$, and $\mathrm{Ni}$ in copper as a function of temperature.
This higher braze temperature also results in the formation of a braze joint which is much wider than the original gold layer thickness.

To help overcome the problem of gold diffusion in copper, a thin layer of nickel was first deposited on the copper, and then the gold was deposited onto the nickel. Nickel was chosen as an intermediate layer for two reasons. First, nickel has a diffusivity in copper that is a factor of 10 lower than gold, and, second, gold-nickel has a melting point minimum at $955^{\circ} \mathrm{C}$ at $18 \mathrm{wt} . \% \mathrm{Ni}$ and is a commonly used braze alloy. Figure 7 compares the diffusivity of gold $\left(A=0.243 \mathrm{~cm}^{2} / \mathrm{s}, Q=197.8 \mathrm{~kJ} / \mathrm{mole}\right)$, nickel $\left(A=0.7 \mathrm{~cm}^{2} / \mathrm{s}, Q=225 \mathrm{~kJ} /\right.$ mole $)$, and silver $\left(A=0.61 \mathrm{~cm}^{2} / \mathrm{s}, Q=194.7 \mathrm{~kJ} / \mathrm{mole}\right)$ in copper as a function of temperature [12].

(a)
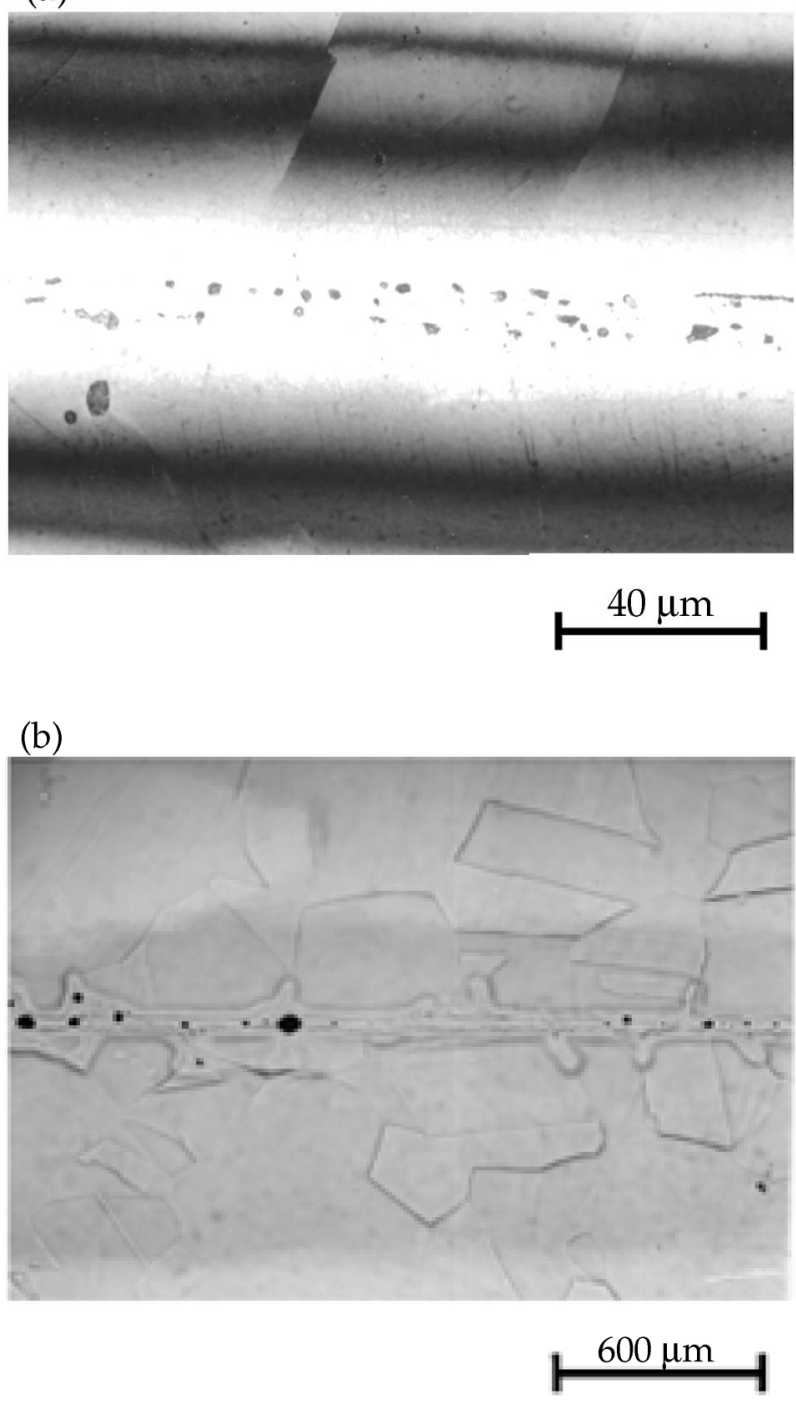

FIG. 8. Microstructures of the PVD deposited $1 \mu \mathrm{m}-\mathrm{Ni} /$ $3 \mu \mathrm{m}-\mathrm{Au}$ vacuum furnace brazes. (a) This braze was heated to $1000{ }^{\circ} \mathrm{C}$, contains porosity, and did not clearly show evidence of melting. (b) This braze was heated to $1060{ }^{\circ} \mathrm{C}$ to ensure melting but produced a very wide joint and contains porosity as well. 
Multilayer coated copper samples were made that consisted of a $1 \mu \mathrm{m}$ thick nickel layer deposited directly onto the copper and a $3 \mu \mathrm{m}$ thick gold layer deposited onto the nickel. Figure 8(a) shows the microstructure of one of these brazes made from the $\mathrm{Ni} / \mathrm{Au}$ multilayer. In this vacuum furnace braze, the temperature was ramped up to $940{ }^{\circ} \mathrm{C}$ in $30 \mathrm{~min}$, held there for $5 \mathrm{~min}$ for temperature stabilization, and then ramped up to $1010{ }^{\circ} \mathrm{C}$ in $10 \mathrm{~min}$ prior to furnace cooling. The joint was observed during brazing and no visible liquid formed on the outside of the part. The microstructure of this joint shows a $32 \mu \mathrm{m}$ wide light-etching region at the joint, which was caused by diffusion of gold and nickel away from the original interface. There was no obvious sign of melting, even though the temperature of the joint surpassed the liquidus minimum of both $\mathrm{Au}-\mathrm{Cu}$ and $\mathrm{Au}-\mathrm{Ni}$. Porosity was present as small voids distributed throughout the central portion of the joint where the original Au and Ni layers existed. The source of this porosity is most likely caused by void formation when the diffusivity of one species is higher than that of the other. This creates vacancy accumulation and void formation on the side of the joint with the faster diffusing species. This void formation mechanism, sometimes referred to as Kirkendall porosity, has been observed in copper-nickel diffusion couples [14]. In the case of the brazes made in this study, the void formation mechanism is more complicated since three diffusing species are present, but the basic effect is still the same.

Since it was not clear how much of the braze shown in Fig. 8(a) had melted, a second braze was made using $1 \mu \mathrm{m} \mathrm{Ni}$ and $3 \mu \mathrm{m} \mathrm{Au}$ coated samples but to higher temperatures. In this braze, the temperature was heated to $1000{ }^{\circ} \mathrm{C}$ in $30 \mathrm{~min}$, and was then ramped up to $1060^{\circ} \mathrm{C}$ in $20^{\circ} \mathrm{C}$ increments at $1 \mathrm{~min}$ intervals. Visible liquid first appeared on the outside of the joint at $1060{ }^{\circ} \mathrm{C}$. Figure 8(b) shows the microstructure of this joint, which indicates that the joint had melted and there was preferential penetration of the braze along the prior copper grain boundaries that intersected the joint. The overall width of the joint exceeded $100 \mu \mathrm{m}$, and porosity was observed throughout the joint. The results of the Au-Ni braze experiments showed that the $1 \mu \mathrm{m}$ thick nickel layer was not successful in preventing diffusion of gold away from the joint under typical furnace brazing conditions. Because of this, the brazing temperature had to be driven well above the melting point minimum in order to melt the braze and, in doing so, the joint widened substantially.

In this investigation, the thin PVD brazes were all made using conventional vacuum furnace brazing at relatively low heating rates, so the effect of heating rate on the quality of these brazes was not determined. However, one would expect that the sputter deposited gold brazes would benefit from higher heating rates, such as those of induction brazing, where there would have been less time for diffusion of gold away from the interface. Also, the addition of a
Sn layer could reduce the braze temperature substantially through the formation of a Au-Sn eutectic [15].

\section{B. Vacuum brazing-braze alloy shims}

Pure silver, pure gold, and an 82 wt. $\% \mathrm{Au}-18$ wt. $\% \mathrm{Ni}$ (Nioro) alloy shims were used in the furnace brazing experiments. These shims measured $25 \mu \mathrm{m}$ thick and were punched to have the same diameter as the reduced section of the test coupon (12 mm diameter). Furnace brazing was done on individual test coupons by heating to a temperature $20^{\circ} \mathrm{C}$ below the braze temperature at a rate of $75^{\circ} \mathrm{C} / \mathrm{min}$, holding it at this temperature for $5 \mathrm{~min}$, and, after a few minutes, heating to the braze temperature. The braze was typically completed in about $1 \mathrm{~min}$ at the braze temperature and then the furnace was turned off to let the sample cool in vacuum. A second set of brazes was performed with induction heating on the gold-containing braze materials at a rate of $250{ }^{\circ} \mathrm{C} / \mathrm{min}$ to the soaking temperature in order to see if higher heating rates would improve the braze quality.

Figure 9 compares the results of the vacuum furnace brazes using radiation heating at rates of $75^{\circ} \mathrm{C} / \mathrm{min}$. Figure 9(a) shows the silver braze that was made at a temperature of $800{ }^{\circ} \mathrm{C}$. This braze shows uniform wetting across the diameter of the part and has a thickness of only $6 \mu \mathrm{m}$. The excess liquid from the braze was drawn to the outside of the joint, which resulted in a joint that was thinner than the original braze foil. This braze showed minimal signs of porosity, and showed some solid-state diffusion of silver into the copper as indicated by the dark etching phase that exists between the eutectic braze and the copper base metal. Thus the higher interfacial pressure that was used to bond this silver joint (3.45 $\mathrm{kPa})$ appeared to be sufficient to keep the interfaces tight and the overall braze thickness small as compared with the PVD deposited silver joints that were bonded at $1.08 \mathrm{kPa}$.

Figure 9(b) shows the gold braze that was made at a temperature of $1000{ }^{\circ} \mathrm{C}$, which has a thickness of $80 \mu \mathrm{m}$, and is considerably thicker than the silver braze. This braze shows signs of porosity along the centerline of the joint, but overall it has less porosity than the sputterdeposited gold braze. Figure 9(c) shows the Nioro braze that was made at a temperature of $980{ }^{\circ} \mathrm{C}$, measuring $25 \mu \mathrm{m}$ thick. This braze also has porosity which is mainly lined up along the edges of the braze joint, but also has some porosity at the centerline.

Figure 10 compares the results of the vacuum induction brazes on the gold-containing braze alloys that were induction heated at $250{ }^{\circ} \mathrm{C} / \mathrm{min}$. Figure 10 (a) shows the pure gold braze that was made at a temperature of $1000{ }^{\circ} \mathrm{C}$ and has a thickness of $60 \mu \mathrm{m}$, which is somewhat thinner than the gold braze made at the lower heating rate. This braze also contains porosity along the centerline, but appears to have less diffusion of Au away from the braze joint than 


\section{(a)}
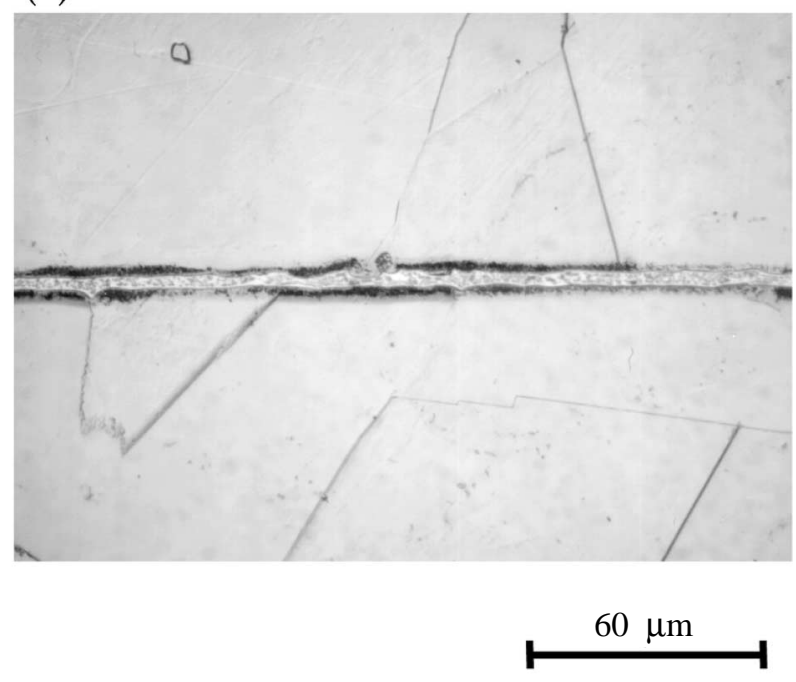

(b)

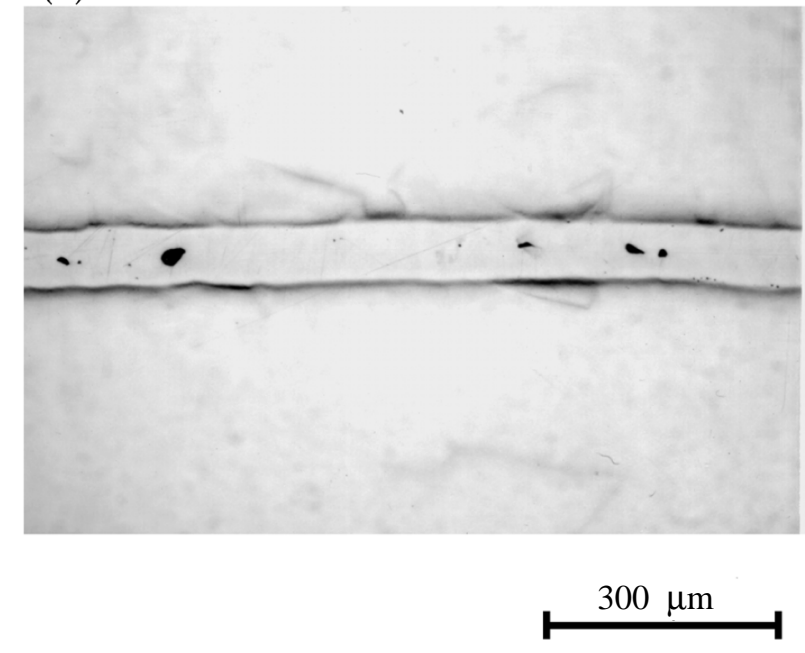

(c)

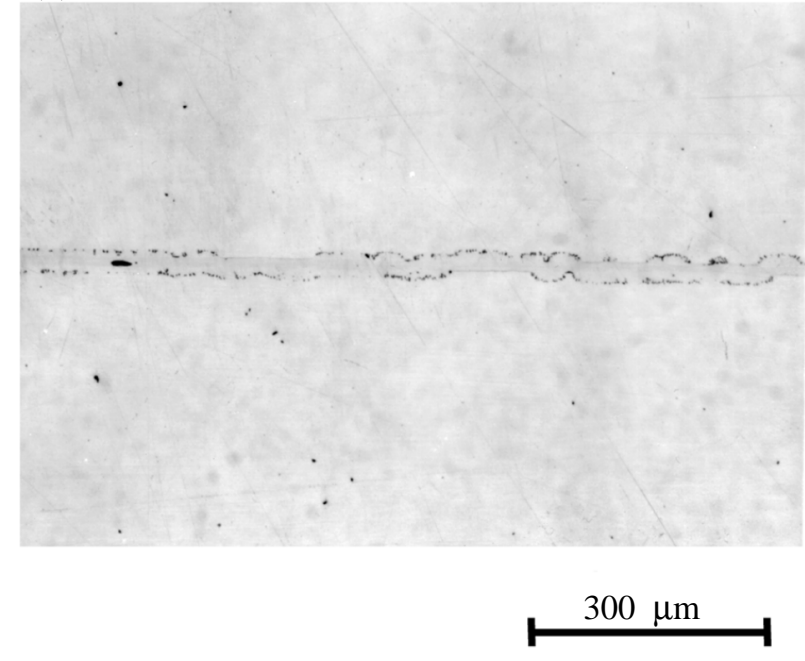

FIG. 9. Microstructures of the shim brazes made under vacuum furnace brazing conditions with radiation heating at $75^{\circ} \mathrm{C} / \mathrm{min}$ : (a) pure silver braze showing good wetting and minimal porosity, (b) pure gold braze with centerline porosity, and (c) Nioro braze with centerline and edge porosity. (a)

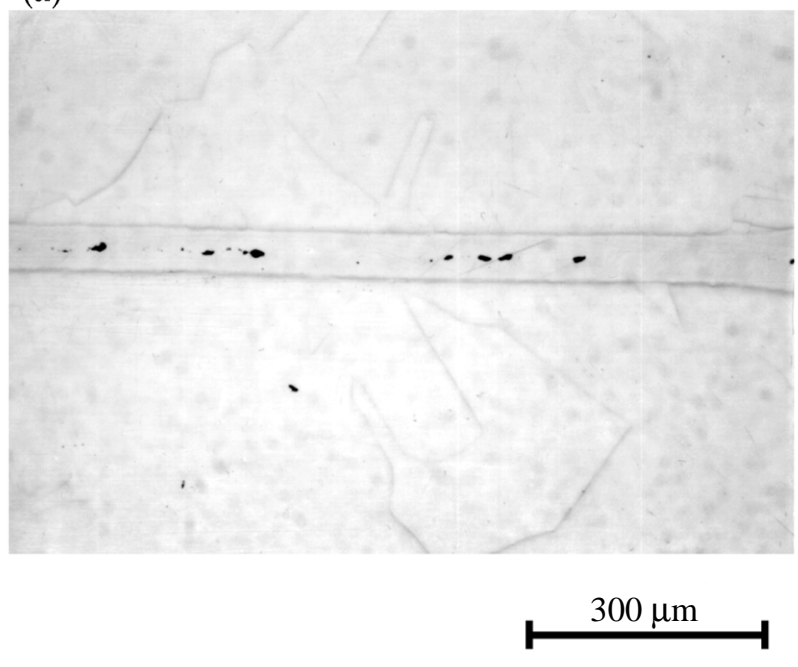

(b)

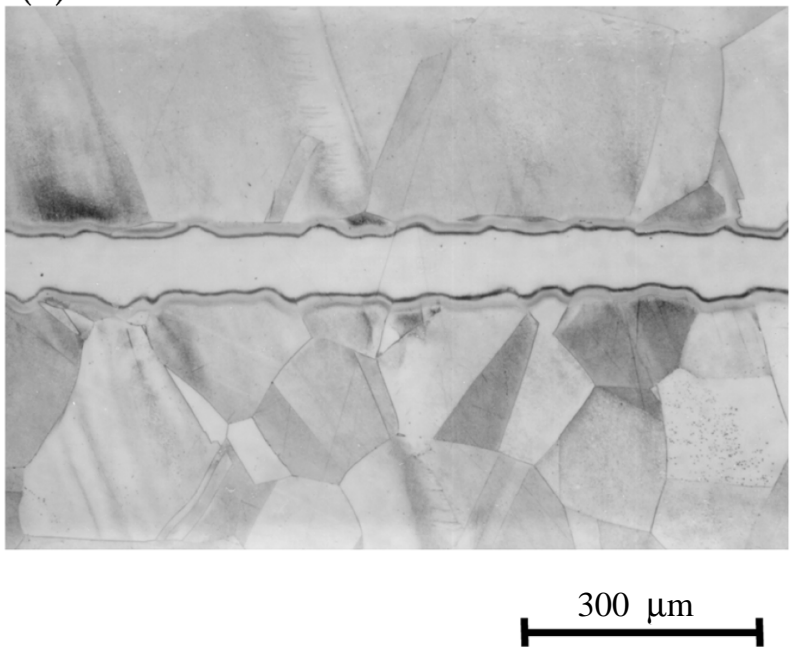

FIG. 10. Microstructures of the shim brazes made under vacuum furnace brazing conditions with induction heating at $250^{\circ} \mathrm{C} / \mathrm{min}$ : (a) pure gold braze showing centerline porosity and (b) Nioro braze with no porosity.

occurred at lower heating rates. Figure 10(b) shows the Nioro braze that was made at a temperature of $980{ }^{\circ} \mathrm{C}$ and has a thickness of $80 \mu \mathrm{m}$, which shows a small diffusion zone of gold away from the braze joint and into the copper. This braze looked very good, showed very little porosity, and was significantly better than the Nioro braze made at lower heating rates.

Overall, the vacuum brazing of the copper parts worked well with $25 \mu \mathrm{m}$ thick shims. Although these shims resulted in thicker joints in general than the PVD deposited layers, they are much less expensive to implement. Of the three braze alloys studied, silver created thin and uniform brazes and worked well at both low and high heating rates. The gold-containing alloys showed considerable diffusion of gold away from the original interface and, in general, 
resulted in porosity along the joint. This porosity was distributed on a finer scale in the Nioro braze than in the pure gold braze. At the highest heating rate no porosity was observed in the Nioro joint.

\section{Diffusion bonding}

A series of diffusion bonds was made to determine the relationship between bond strength and bonding parameters in order to determine a range of bonding conditions that could be used to produce satisfactory joints in high purity copper. These tests were made over a range of temperatures with two different bonding pressures and with two different surface finishes. In these studies, the bonding time was held constant at $60 \mathrm{~min}$ at the top temperature, following a $30 \mathrm{~min}$ ramp to the top temperature. Although diffusion bonding conditions for copper have previously been investigated [16], these conventional diffusion bonding tests have been performed using high bonding forces where macroscopic deformation of the parts occurs.

As previously mentioned, the brazing or bonding process must be repeatable for the NLC production solution. This concept also applies to deformations either through creep or actual yielding of the copper around the joint during bonding. If the geometry of the cell cavity is changed slightly but repeatedly with cell number, it can be calibrated. However, minimizing deformation is our first choice and, therefore, the pressures used in this study were kept intentionally low. The first loading condition consisted of only the load of the samples themselves, i.e., with no external load applied. Based on the test sample weight and geometry, the interfacial pressure at the reduced section was $3.45 \mathrm{kPa}(0.50 \mathrm{psi})$ when no external load was applied. The second loading condition consisted of applying $327 \mathrm{~N}$ to the test sample arrangement, which resulted in an interfacial pressure of $3.45 \mathrm{MPa}(500 \mathrm{psi})$. This stress results in a creep rate of $10^{-2} \%$ per hour at $650^{\circ} \mathrm{C}$ [17]. This load was applied in a uniaxial vacuum press. The load was maintained perpendicular to the bonding surface by transmitting the load through $4.5 \mathrm{~mm}$ diameter, spherical, steel ball bearings that were centered using the holes drilled through the center of the parts.

The fabrication of the coupons is described in Sec. II B. In summary, the two different surface finish conditions consisted of (i) fly-cut parts as produced by an outside vendor and (ii) these same parts that had been annealed at $500{ }^{\circ} \mathrm{C}$ and refinished at LLNL using a diamond-turning operation as indicated in Fig. 5. The fly-cut parts have a surface flatness better than $250 \mathrm{~nm}$, but have a waviness error with a period of about $2 \mathrm{~mm}$. The diamond-turned parts are more conventional in appearance, with flatnesses in the $100 \mathrm{~nm}$ range and surface finish less than $500 \AA$, limited mainly by the tool radius effect making circumferential tool grooves at the feed per spindle revolution increment.
A scanning electron micrograph (SEM) of the diamondturned surface is shown in Fig. 11. Grain boundaries appeared on this surface after the annealing cycle and were caused by a thermal grooving mechanism [18]. The depth of these grooves depends on the character of the grain boundary and results in different depths of grooves on the same surface.

The initial set of bonds was made using no applied load on the diamond-turned parts, starting at $1000^{\circ} \mathrm{C}$, and then at successively lower temperatures until a temperature was reached where the bond had no strength. This zero-strength bonding temperature at zero applied load was $700{ }^{\circ} \mathrm{C}$ for the diamond-turned parts and was repeated for confirmation. These results are summarized in Table II and are plotted in Fig. 12 (solid circles), showing that the breaking strength of the bond was around $22000 \mathrm{~N}$ for $1000{ }^{\circ} \mathrm{C}, 900{ }^{\circ} \mathrm{C}$, and $800^{\circ} \mathrm{C}$, but quickly drops to zero at $700{ }^{\circ} \mathrm{C}$.

The fly-cut parts that were bonded with no applied load were then made and tested. It was determined that these samples had bond strengths considerably less than their diamond-turned counterparts. Figure 12 compares these results (inverted triangles) with the other data and shows that the fly-cut bond had a strength of $7205 \mathrm{~N}$ at $900{ }^{\circ} \mathrm{C}$, whereas the diamond-turned bond had a strength of $23796 \mathrm{~N}$. The bond strength of the fly-cut parts decreased with bonding temperature to zero bond strength at $700{ }^{\circ} \mathrm{C}$, which is the same temperature where the diamondturned surfaces showed zero strength when no loads were applied during bonding. The next set of bonds was made under the $3.45 \mathrm{MPa}(500 \mathrm{psi}$ ) condition, and bonds were made on both the diamond-turned (solid squares) and the fly-cut (diamonds) surfaces. These parts showed maximum strength $(\sim 22000 \mathrm{~N})$ for bonding temperatures of $700{ }^{\circ} \mathrm{C}$ and higher. This is a marked improvement over the parts bonded with no load, which had zero strength at $700{ }^{\circ} \mathrm{C}$ for both surface conditions. Some bonds were

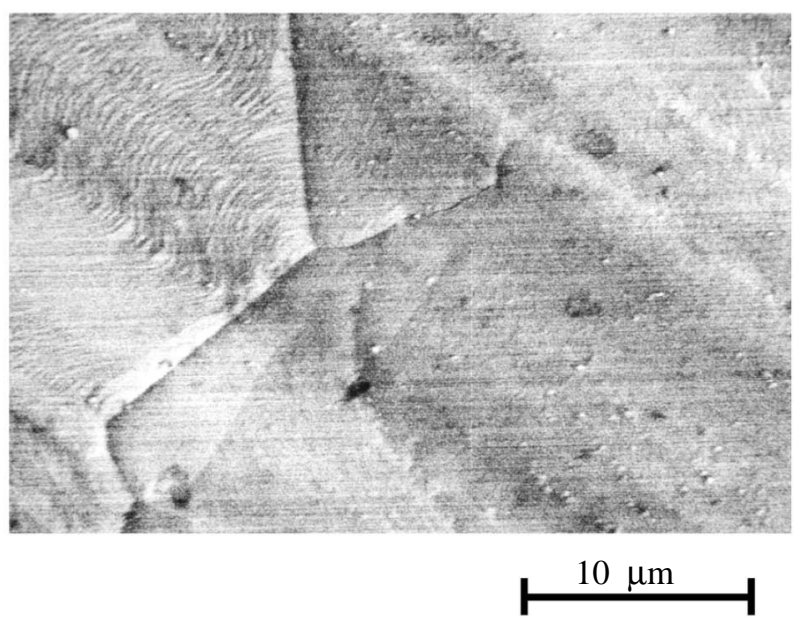

FIG. 11. SEM image of the diamond-turned surface. Grain boundary grooves are visible after annealing. 
TABLE II. Room temperature breaking strength (Newtons) for the diffusion bonded samples having a bonded area of $1.13 \times 10^{-4} \mathrm{~m}^{2}$. DT refers to the diamond-turned finish; DFC refers to the diamond fly-cut finish.

\begin{tabular}{cccccc}
\hline \hline $\begin{array}{c}\text { Bonding } \\
\text { Temp. }\left({ }^{\circ} \mathrm{C}\right)\end{array}$ & $\begin{array}{c}\text { DT } \\
\text { No load }\end{array}$ & $\begin{array}{c}\text { DFC } \\
\text { No load }\end{array}$ & $\begin{array}{c}\text { DT } \\
3.45 \mathrm{MPa}\end{array}$ & $\begin{array}{c}\text { DFC } \\
3.45 \mathrm{MPa}\end{array}$ & $\begin{array}{c}\text { Silver } \\
\text { braze }\end{array}$ \\
\hline 400 & & & & 7339 & \\
500 & & & 11164 & 10497 & \\
600 & & & 19571 & & \\
700 & 0 & 0 & 21528 & & \\
800 & 20905 & 2157 & 20104 & & \\
900 & 23796 & 7205 & & & \\
1000 & 21039 & & & & \\
\hline \hline
\end{tabular}

made at temperatures as low as $400{ }^{\circ} \mathrm{C}$, and these bonds continued to display significantly high breaking strengths but would not have been leak tight. Comparison of the bond strengths made on the fly-cut and diamond-turned surfaces indicated that both finishes produced the same strength bond at $600{ }^{\circ} \mathrm{C}$.

The strengths of the diffusion bonds were compared with the strength of a silver braze in order to determine the relative effectiveness of the diffusion bonding process. The ultimate tensile strength of annealed oxygen-free highconductivity copper (OFHC) is $230 \mathrm{MPa}$ [17], which corresponds to a breaking load of $26000 \mathrm{~N}$ for the $12 \mathrm{~mm}$ diameter reduced-section diameter bar. This load is shown as the dashed line in Fig. 12 and is approximately $10 \%$ higher than the breaking strength of the strongest diffusion bond, illustrating that diffusion bonds can attain a mechanical joint efficiency of $90 \%$. The silver braze was made with a $50 \mu \mathrm{m}$ thick foil on fly-cut surfaces and was brazed at $800{ }^{\circ} \mathrm{C}$. This braze had a breaking strength of $19473 \mathrm{~N}$, which was similar to, but not as high as, the diffusion bonds made at $800{ }^{\circ} \mathrm{C}$. Therefore, it can be concluded that well-made diffusion bonds can be as strong, or stronger than, silver brazes when the bonding conditions

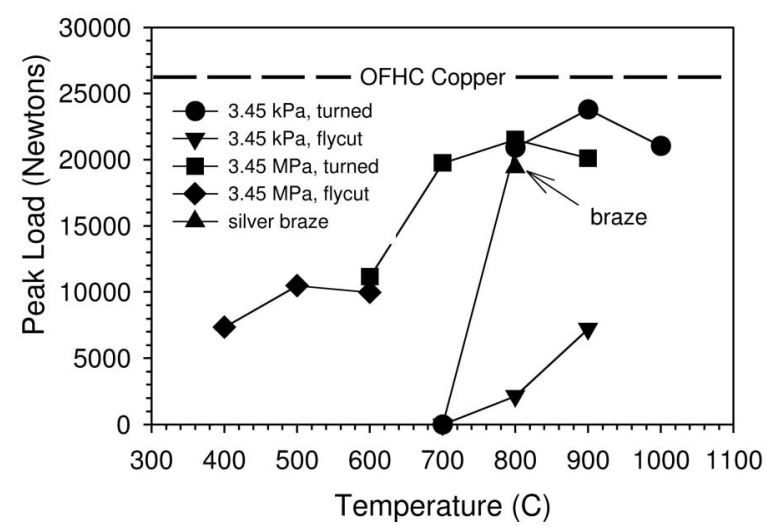

FIG. 12. Diffusion bond strength for two different bonding pressures [3.45 $\mathrm{kPa}(0.5 \mathrm{psi})$ and $3.45 \mathrm{MPa}(500 \mathrm{psi})]$ and two different surface finishes (diamond turned and diamond fly cut) as a function of temperature. The strength of a silver braze (triangle) is shown at $800{ }^{\circ} \mathrm{C}$ for comparison. are correct, and can reach mechanical strengths of $90 \%$ of the base metal strength.

The bond strength versus bonding temperature data plotted in Fig. 12 appear to have significant scatter. However, several trends appear in the data after grouping them into different categories of surface finish and bonding pressure. The poorest bonding conditions were created from the fly-cut surfaces that were bonded with no applied load (inverted triangles). These samples had zero strength under the $700{ }^{\circ} \mathrm{C}$ bonding condition and had only moderate breaking strength $(7205 \mathrm{~N})$ at bonding temperatures as high as $900{ }^{\circ} \mathrm{C}$. This makes sense since the microscopic area of contact for the diamond fly-cut surfaces is small. Only the peaks of the waviness interact, severely reducing the bonding area that is needed to produce high strength bonds. The strongest set of bonds was made on the diamond-turned parts at both high and low bonding pressures where breaking strengths of approximately $22 \mathrm{kN}$ were achieved for bonding temperatures of $700{ }^{\circ} \mathrm{C}$ and higher. At lower temperatures, bonds with moderate breaking strengths $(7.4 \mathrm{kN})$ could be achieved as low as $400{ }^{\circ} \mathrm{C}$. These bonds were made on diamond fly-cut parts

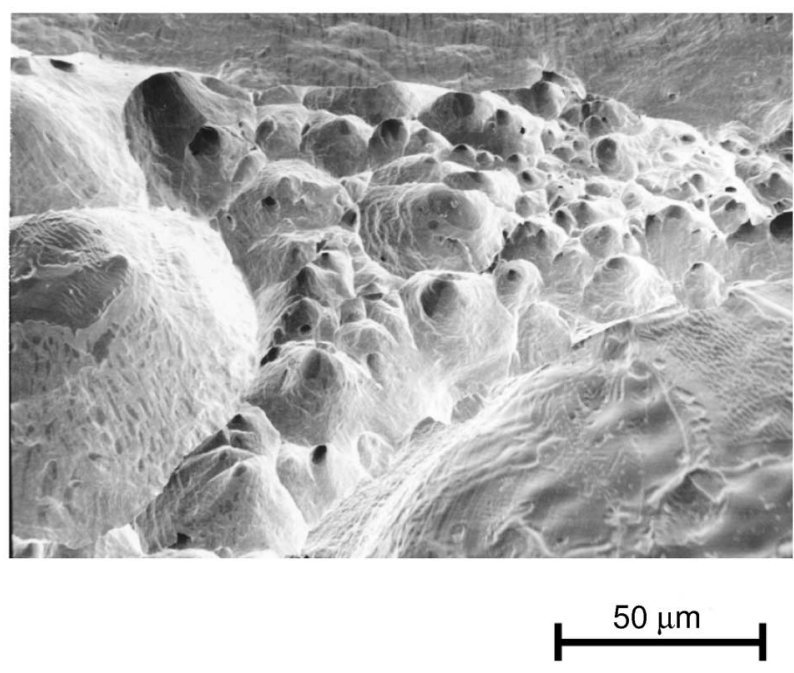

FIG. 13. SEM image of the fracture surface of the silver brazed joint showing a very ductile fracture. 
with significant waviness where point asperity contact was made [see Fig. 14(b)]. Although these parts were not leak checked, it should be noted from the appearance of the fracture surface that only the highest strength bonds appear sufficiently bonded to be vacuum tight, and that the bonds made at lowest temperatures would almost certainly not be vacuum tight.

SEM images of the fracture surfaces from the diffusion bonded and brazed samples revealed additional details about the bonding mechanisms. Figure 13 shows an SEM image of the fracture surface of the silver braze. This braze had a very ductile appearing fracture surface that was characterized by large dimpled areas where some of the dimples were in excess of $100 \mu \mathrm{m}$. Some of these dimples were probably the result of porosity that was

(a)

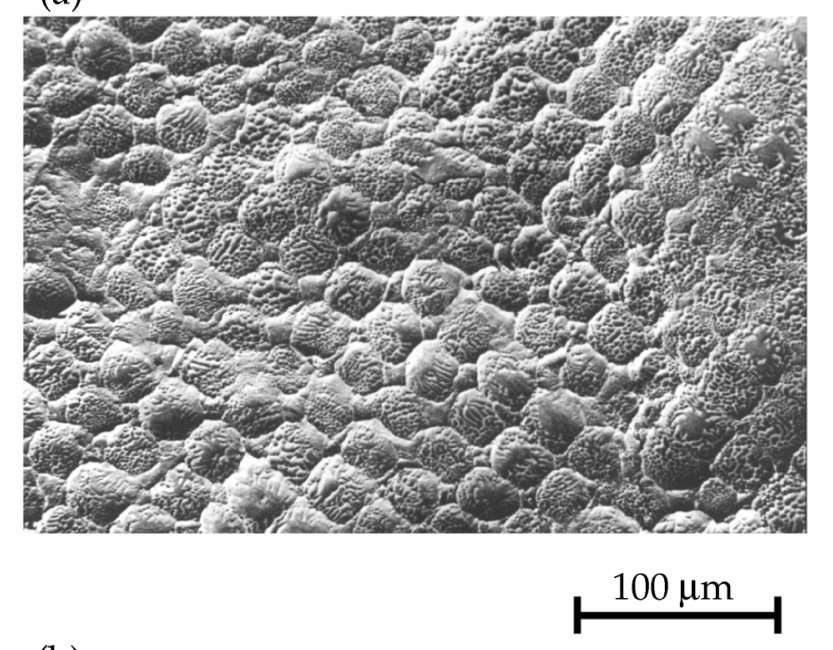

(b)

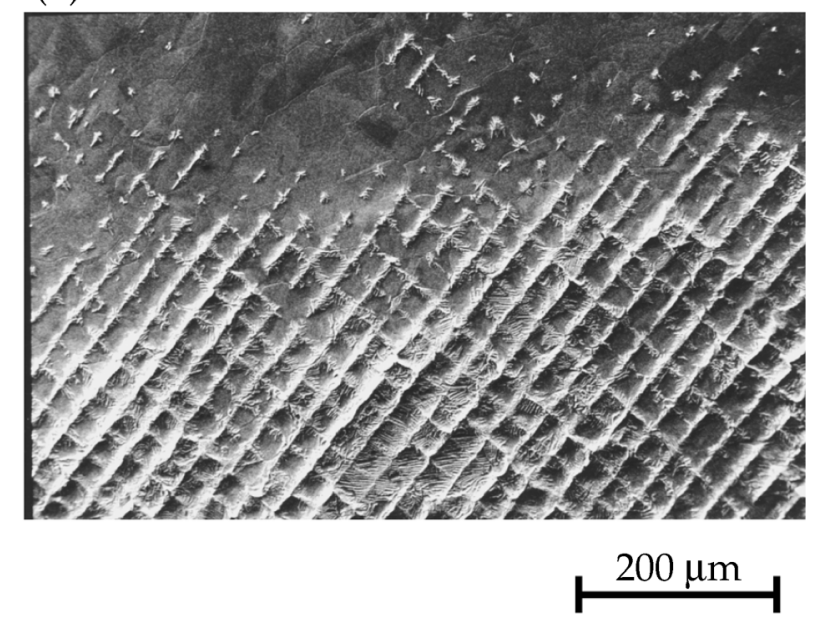

FIG. 14. SEM image of the fracture surfaces from $600{ }^{\circ} \mathrm{C}$ diffusion bonded parts that had been diamond fly cut. (a) Region of good bonding showing dimples spaced approximately $25 \mu \mathrm{m}$ apart. (b) Transition region between good bonding (bottom of micrograph) and poor bonding (top of micrograph) showing ridge-to-ridge asperity contact in a regular array, which was caused by the contact of machining grooves placed approximately at right angles to each other. present in the braze which provided preexisting cavities that preferentially initiated fracture.

Figure 14(a) shows the fracture surface of a fly-cut and diffusion bonded sample. This sample was bonded at $600{ }^{\circ} \mathrm{C}$, and the fracture surface shows an array of uniformly spaced dimples, spaced approximately $25 \mu \mathrm{m}$ apart. It is believed that the origin of these dimples was related to the overlapping of the tool marks [not the waviness shown in Fig. 5(a)] produced during fly cutting, where local points of contact were created in a regular array. This was shown to indeed be true when a fly-cut surface was bonded with a no-axial load. This loading condition produced a bonded sample where only one-half of the sample was bonded; Fig. 14(b) shows a micrograph of the transition region between the poorly bonded and the wellbonded regions of this sample. In this micrograph it is clear that the ridges from one side of the sample were

(a)

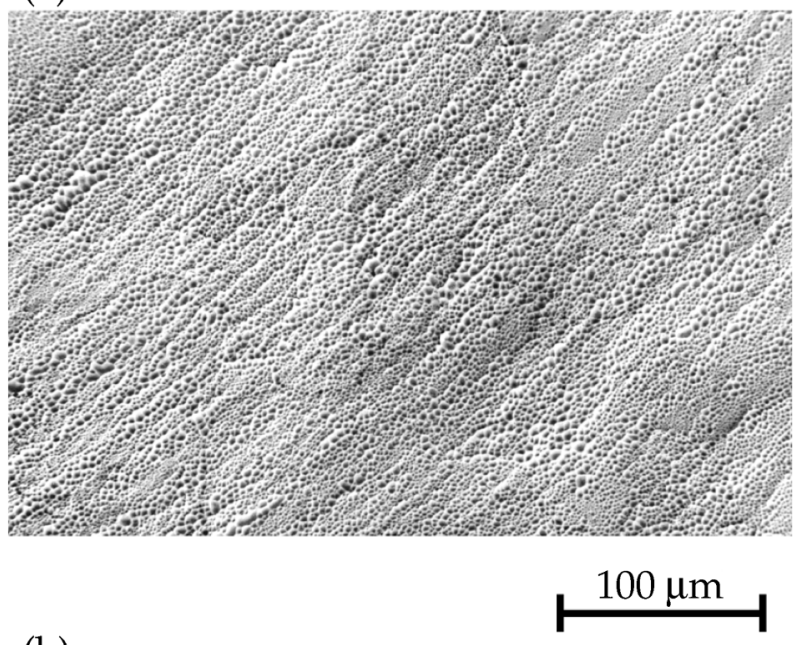

(b)

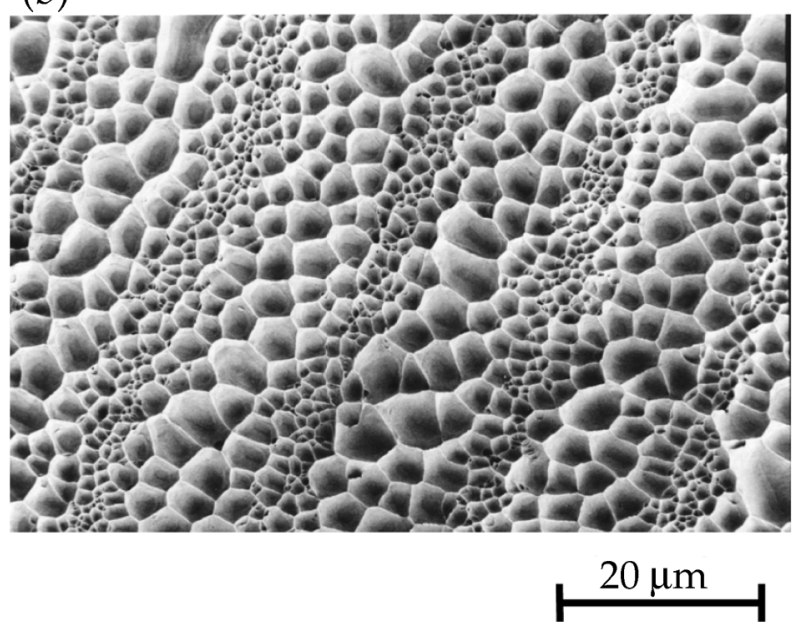

FIG. 15. SEM image of the fracture surface from $800{ }^{\circ} \mathrm{C}$ diffusion bonded parts that had been diamond turned. (a) The dimple pattern is radial, which corresponds to the machining grooves left during the turning operation. (b) The dimple pattern at higher magnification shows alternating bands of small and large dimples. 
contacting the ridges of the other side of the sample at nearly right angles to produce a grid of asperity contact with a spacing of about $25 \mu \mathrm{m}$.

The fracture surfaces from the bonds made from the diamond-turned parts have a different appearance from those of the fly-cut parts. Figure 15(a) shows an SEM image of the fracture surface of a diamond-turned part that was bonded with no applied load at $800{ }^{\circ} \mathrm{C}$. The magnification used in this micrograph shows that the fracture surface is made up of azimuthal rows of dimples with a radial spacing of approximately $20 \mu \mathrm{m}$. This pattern is related to the diamond machining grooves that created ridges and valleys on the surface of the part. Figure 15(b) provides a closer look at the dimples, which clearly shows alternating rows of dimples of small and large diameter. This pattern of dimples was created during fracture, where the only bonding had occurred locally at ridge-to-ridge contact points.

\section{CELL ASSEMBLY AND JOINING PROCESS}

The current prototype design structure assembly procedure consists of stacking the diamond-turned copper cells in a V-block assembly inclined at an angle to gravity for radial and axial positioning of the flat surfaces. The $1.8 \mathrm{~m}$ long structure is later placed in a bonding furnace and heated to a temperature of $890{ }^{\circ} \mathrm{C}$ to diffusion bond the individual cells together [5]. As part of a group working on structures for the NLC, the authors are considering an alternate stacking and bonding procedure whereby a locating feature is built directly into the cells for alignment, thus removing the need for V-block assembly. This proposed design incorporates a step joint, schematically shown in Fig. 16. The crosshatched region on the cell top view is the only portion of the cell that will be diffusion bonded, and a braze alloy insert will be placed on the exterior surface to create a braze joint as indicated.

This design divides the responsibility for the functions of axial and radial constraints into separate features. The axial-normal surface constrains the axial position and rotations about the axes normal to the beam axis. The two radial constraints are provided by the interference step joint. Rotation about the beam axis is a loose tolerance and can be set by other means. This approach offers considerable advantage in obtaining cell-to-cell concentricity of the irises and cavities over the use of the outside diameter mounted in tooling such as a V-block during structure assembly. The interference joint will allow for larger tolerances on the radial locating features because errors in this feature lead to a change in the stress in the interference joint, not alignment (nonconcentricity) errors.

At this point, we emphasize that the proposal for a new fabrication and assembly procedure should be taken in the spirit of an interesting future direction for investigation and does not represent a final or optimized design. Indeed, much analysis needs to be done with regards to both its

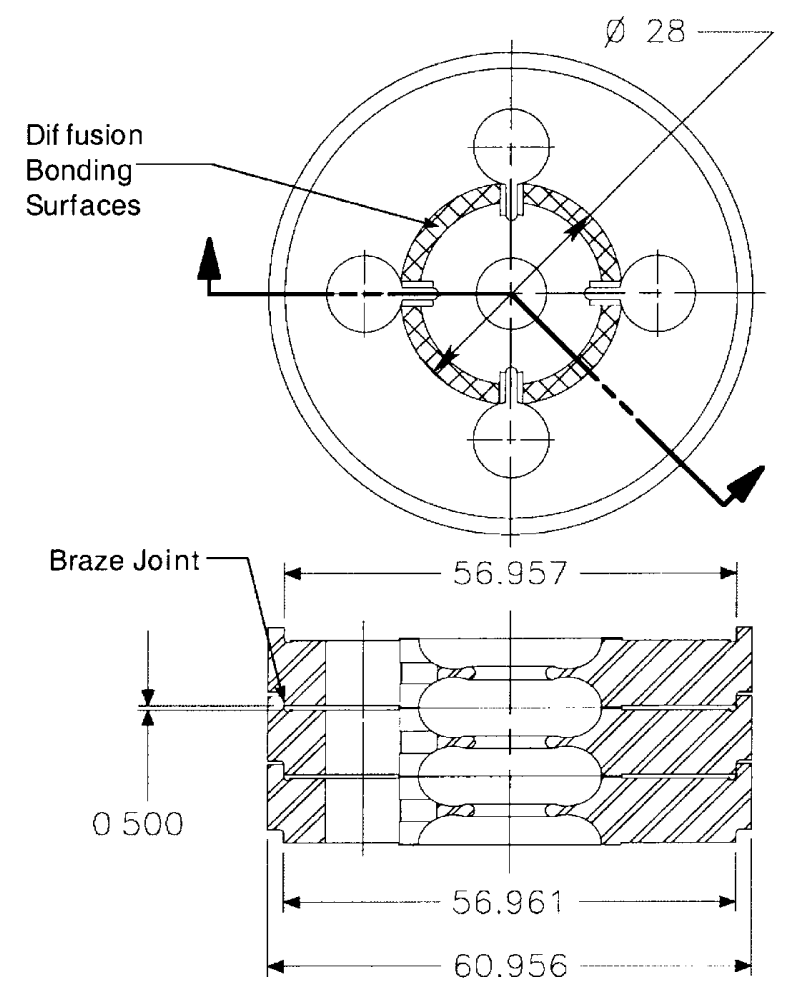

FIG. 16. Schematic illustration of the conceptual design.

specific engineering implementation and its implications for vacuum and microwave performance.

One concern of this design is the size (diameter) of the axial land at approximately half the overall cell diameter. This reduction in axial bearing diameter by approximately a factor of 2 leads to an increase in the ratio of stack height (1.8 $\mathrm{m}$ for 206 cells) to bearing diameter from 30:1 to 60:1. This diameter change is quite important for the stability of a compressively loaded column. However, in the current design proposal, the axial land provides alignment for only 3 degrees of freedom for each cell-to-cell interface. After the assembled cells are at the same temperature, the outer interference feature will grip the adjacent cell, providing stability via friction until brazing has occurred at this joint.

We have some experience in achieving intimate contact in face-to-face joints. The vacuum chucks that we use on our diamond-turning lathes are designed to have near zero tolerance for gaps between the part and the chuck, not for vacuum reasons but rather to allow the vacuum chuck to be used as the precision datum for facing operations on the part. A typical acceptable error or gap between the part and the chuck is less than $0.1 \mu \mathrm{m}$. The usual culprit in cases of poor performance is particulate contamination causing a small gap between the part and the chuck, and a key to a successful chuck design is to minimize the interfacial surface area, thus reducing the likelihood for a compromised joint. In the current design proposal, the small 
axial land is a moderate step in the reduction of cell-to-cell surface area and in the likelihood of contamination causing nonparallel cells.

Additionally, we have assembled several cell pairs with this method and have achieved better than $50 \mu \mathrm{rad}$ of angular misalignment between cell pairs. This translates into a $1.5 \mu \mathrm{m}$ tilt at the cell-to-cell interface. This is, or is very close to, acceptable for the NLC specification, but we feel that it is reasonable to be able to achieve better than $0.25 \mu \mathrm{m}$ of tilt at these interfaces. This is an area of focus for our current NLC program at LLNL that will result in cell assembly tests to verify the design concept.

In this design, mating faces will be diamond turned to finish and flatness requirements appropriate for diffusion bonding, but only in the region around the cavity. In previous prototype designs, the entire face was diamond turned, whereas in this design a much smaller surface will need to be diamond turned. This reduction in the amount of diamond turning should lead to an increase in the overall production speed, which, in turn, should contribute to an overall reduction in cost.

The reduced amount of diffusion bond area in the proposed design as compared to the current prototype design results in a diffusion bond with less strength. To compensate for the reduced bond strength, we further propose to braze the cells together after the diffusion bond has been made. The brazing process will utilize a preplaced braze alloy insert that will react with the copper to form a liquid braze alloy. This braze will ensure that the joint is leak tight and will provide the required strength to the joint. In addition, the braze will be designed to wet around the step joint mating surfaces to seal the assembly and to provide additional strength to the joint.

Based on the results of the brazing and bonding studies performed in this investigation, a set of preliminary joining procedures was developed. The procedure will consist of assembling the cells one at a time, using differential heating to overcome a slight radial interference fit at the step joint. At this time, a braze alloy insert will be placed at the outside diameter of the cell where the braze is to be made. When the 206 cell stack is assembled, it will be placed in a vacuum furnace with the appropriate fixturing for mechanical stability and to apply a suitable end load on the stack. Next, with the braze alloy inserts in place, the diffusion bond will be made by slowly heating to the bonding temperature and holding at this temperature for the necessary time to make the bond. After the diffusion bond is complete, the temperature on the stack will be increased to the brazing temperature and held there for a few minutes to allow the braze to wet the critical interfaces. When the braze is completed, the stack will be slowly cooled to room temperature to minimize residual stresses and distortion prior to removing it from the furnace.

Pure silver is the first choice for the braze alloy based on the results of the brazing studies. This alloy brazed uniformly well under all brazing conditions and did not require excessive braze temperatures. If pure silver is used for brazing, diffusion bonding will need to be performed at a temperature less than the $\mathrm{Ag}$-Cu eutectic $\left(780^{\circ} \mathrm{C}\right)$. Since all bonds made at temperatures less than $800^{\circ} \mathrm{C}$ required pressure in order to create good bonds, we need to ensure that all of the interfaces are receiving sufficient pressure during the bonding cycle. Our experience so far suggests that $3.45 \mathrm{MPa}$ (500 psi) pressure would produce full strength bonds at $700{ }^{\circ} \mathrm{C}$ (see Fig. 12). This pressure can be applied through an axial load to the stack. Finite element calculations on an assembled stack of cells show that the stiffness of the axial load path is much higher than that through the interference fit joint. Thus there is little reduction in the pressure on the axial lands due to the friction on the interference joint, which allows nearly all of the load to be transmitted through successive cells where the diffusion bonds are to be made.

One additional point that needs to be considered is that the inherent weight of the stack of cells will produce a gradient of pressures from top to bottom. Therefore, by adding enough load to produce $3.45 \mathrm{MPa}$ (500 psi) on the top cell of the stack, cells on the bottom will have pressures in excess of the target value. This problem can be avoided by designing the cells to have increasing amounts of bonding area from top to bottom of the stack. Since each cell is slightly different through the stack due to other reasons, an additional parameter that would allow variable bond area is of little consequence. Variable bond areas may be required if the amount of applied load necessary to produce good bonds on the top of the stack results in excessive deformation to the cells on the bottom. An alternate approach that would require two bonding steps is also possible. In this approach, load is applied to the stack to produce the proper bonding pressure on the bottom cells of the stack, which leaves insufficient pressure on the top cells. After the first bonding cycle, the stack is inverted and a second bonding cycle is applied, this time to produce good bonds on the opposite end of the stack.

Since the combination of diffusion bonding and brazing has not yet been performed on sample cell geometries, there are still some fabrication issues that need to be resolved through additional experimentation. The major issues will be the exact design of the step structure which will need to provide the necessary alignment and allow pressure to be distributed uniformly on the surfaces to be bonded. Another issue will be the design of the dimensions of the interfaces to be diffusion bonded. Each cell may require different bond areas to accommodate the pressure gradients that result from the inherent weight of the stack. A third issue will be the design of the braze joint and placement of the braze alloy inserts.

Additionally, we note that this design introduces small periodic gaps in the damping manifold, which are designed to carry away power coupled out from the unwanted beamdeflection modes in the accelerating cells. If the gaps are sufficiently narrow, the wall currents should not be 
appreciably perturbed, and thus would not be expected to impede propagation of the $\mathrm{TE}_{11}$ manifold mode. Such gaps, however, may imply reduced pumping efficiency for the structure, particularly if they are very narrow. Thus, both the microwave and vacuum characteristics of this design need to be investigated, especially as a function of the width of the residual gap.

\section{CONCLUSIONS AND RECOMMENDATIONS}

\section{A. PVD brazes}

PVD braze alloy coatings of $\mathrm{Ag}, \mathrm{Au}$, and Ni were deposited on copper substrates in $\mu \mathrm{m}$ thick layers. Brazes made with $4 \mu \mathrm{m}$ thick silver layers worked better than the gold containing brazes under normal furnace brazing conditions. The gold brazes displayed significant porosity throughout the joint and, because of the high diffusivity of gold in copper, they required brazing temperatures in excess of $1000{ }^{\circ} \mathrm{C}$ to ensure liquid formation. It was determined that a thin (1 $\mu \mathrm{m}$ thick) nickel interlayer between the gold and the copper was not sufficient to prevent diffusion of gold away from the braze interface under normal furnace brazing conditions $\left(30^{\circ} \mathrm{C} / \mathrm{min}\right.$ heating rates). The silver brazes showed the formation of an eutectic liquid at a braze temperature of $800{ }^{\circ} \mathrm{C}$, with minimal diffusion of silver away from the braze interface. However, the silver brazes made on these test coupons with $1.0 \mathrm{kPa}$ interfacial pressure were relatively thick $(16 \mu \mathrm{m})$ and contained some large pores. It is believed that the pressure acting on the joint was not sufficient to overcome the high surface tension of the liquid silver copper alloy and caused the top half of the test sample to "float" on the bottom half of the sample. This problem could be easily solved by increasing the pressure on the joint to help keep the two interfaces in closer contact during brazing.

\section{B. Braze allow shims}

Successful brazes were made with $\mathrm{Ag}, \mathrm{Au}$, and $\mathrm{Au}-\mathrm{Ni}$ braze alloy shims under low and high heating rate conditions. At heating rates of $75^{\circ} \mathrm{C} / \mathrm{min}$, the silver shim brazed the best, producing a uniform braze with a thickness of $6 \mu \mathrm{m}$ and minimal porosity. An interface pressure of $3.45 \mathrm{kPa}$ was used on these parts and was found to be sufficient to squeeze the parts together and produce a small amount of liquid silver-copper material on the outside diameter of the braze interface. Under this same heating rate condition, the $\mathrm{Au}$ and $\mathrm{Au}-\mathrm{Ni}$ brazes were significantly wider than the silver braze and contained porosity throughout the joint. However, these joints were considered to be good leak-tight brazes with sufficient strength for the intended application. Higher heating rate brazes $\left(250{ }^{\circ} \mathrm{C} / \mathrm{min}\right)$ were produced by induction brazing in an attempt to reduce the joint thickness and minimize porosity in the gold containing brazes. This higher heating rate was successful in producing joints with less porosity, par- ticularly in the Nioro braze, but the overall joint thickness was approximately the same under both the low and high heating rate conditions.

\section{Diffusion bonds}

Diffusion bonds were made with two different pressures and two different surface finishes, yielding four different bonding conditions. Bonds were made for each of the four conditions over a range of bonding temperatures in vacuum. Comparisons of the bond capability for these different conditions were determined by uniaxial tensile testing of the bonded joints and revealed several important trends. First, under optimum conditions, diffusion bonds were made that had strengths equal to or greater than that of the silver brazed parts. Second, all bonds made with low interfacial pressure [3.45 $\mathrm{kPa}[0.5 \mathrm{psi})]$ had zero strength at bonding temperatures of $700{ }^{\circ} \mathrm{C}$ and lower. Third, the fly-cut parts showed considerably less strength than the diamond-turned parts at bonding temperatures of $800{ }^{\circ} \mathrm{C}$ and $900{ }^{\circ} \mathrm{C}$ under the low bonding pressure condition. Fourth, the application of bonding pressure [3.45 MPa (500 psi)] significantly enhanced the strength of parts bonded at $700{ }^{\circ} \mathrm{C}$ and lower, but had little effect on the strength of parts bonded at $800{ }^{\circ} \mathrm{C}$ and higher. Fifth, moderate strength bonds were made at temperatures as low as $400{ }^{\circ} \mathrm{C}$ with the application of $3.45 \mathrm{MPa}$ (500 psi) bonding pressure on the fly-cut parts with surface waviness. Extrapolation of the bond strength with temperature indicates that low-strength diffusion bonds could be made at temperatures lower than $400{ }^{\circ} \mathrm{C}$ if necessary.

\section{Recommendations for assembly}

The results of this investigation show the feasibility of a two-step diffusion bonding/brazing method for fabrication on a self-aligning step-joint cell design. The proposed process would be to assemble the stack of 206 parts with pure silver braze alloy shims placed at the exterior of the cell-to-cell interface. The stack would then be heated in a vacuum furnace to the diffusion bonding temperature of $700{ }^{\circ} \mathrm{C}$ for sufficient time to make the bond $(\sim 1 \mathrm{~h}$ at temperature) with an applied load of $3.45 \mathrm{MPa}(500 \mathrm{psi})$. After diffusion bonding, the temperature of the stack would be increased to $800^{\circ} \mathrm{C}$ to make the braze. The braze will ensure that a vacuum tight seal is created around the outer portion of the structure and will provide additional strength to the finished assembly. The stack will then be vacuum cooled slowly to room temperature at a controlled rate to minimize distortion and residual stresses. We stress that engineering details and microwave and vacuum characteristics of this proposed design still require analysis.

\section{ACKNOWLEDGMENTS}

This work was performed under the auspices of the U.S. Department of Energy, Lawrence Livermore National 
Laboratory, under Contract No. W-7405-ENG-48. The authors express their gratitude to Mr. L. Wagner for performing all vacuum brazing, diffusion bonding, and annealing experiments, Mr. R. Kershaw for optical metallography, Mr. J. Ferreira for scanning electron microscopy, and Ms. C. Evans for x-ray photoelectron spectroscopy. The LLNL document number for the original release of this paper is No. UCRL-JC-135547, Rev 5.

[1] NLC Design Group, LBNL Report No. LBNL-5424, SLAC Report No. SLAC-474, LLNL Report No. UCRLID-124161, LBNL Report No. UC-414, Vol. 1, 1996; http://www.slac.stanford.edu/

[2] J.W. Wang et al., in Proceedings of the 1999 Particle Accelerator Conference, New York (IEEE, Piscataway, NJ, 1999), pp. 3423-3425.

[3] J. Klingmann et al., in Proceedings of the 1999 Particle Accelerator Conference, New York (Ref. [2]), pp. 777-779.

[4] H. A. Hoag et al., in Proceedings of the 1993 Particle Accelerator Conference, Washington, DC (IEEE, Piscataway, NJ, 1993), pp. 907-909.
[5] K. Asano et al., in Proceedings of the 1999 Particle Accelerator Conference, New York (Ref. [2]), pp. 3417-3419.

[6] I. Wilson and W. Wuensch, CERN Report No. CLICNOTE-145, 1991.

[7] Work performed by Vectron Corp., 1997.

[8] C. Evans (private communication).

[9] E. Paul et al., Precis. Eng. 18, 4-19 (1996).

[10] Binary Alloy Phase Diagrams, edited by T. B. Massalski (ASM International, Metals Park, OH, 1992), 2nd ed.

[11] W. D. MacDonald and T. W. Eager, Metall. Mater. Trans. 29A, 315 (1998).

[12] Smithells Metals Reference Book, edited by E. A. Brandes and G. B. Brook (Butterworths and Heinemann, London, 1992), 7th ed.

[13] J. W. Christian, The Theory of Transformations and Alloys, Part 1 (Pergamon, New York, 1975), 2nd ed.

[14] R. S. Barnes and D. J. Mazey, Acta Metall. 6, 1 (1958).

[15] R. Venkatraman, J.R. Wilcox, and S. R. Cain, Metall. Mater. Trans. 28A, 699 (1997).

[16] G. W. Cunningham and J. W. Spretnak, Trans. AIME 227, 7 (1963).

[17] Metals Handbook (ASM International, Metals Park, OH, 1979), 9th ed., Vol. 2, p. 277.

[18] L.E. Murr, Interfacial Phenomena in Metals and Alloys (Addison-Wesley, Reading, MA, 1975). 